\title{
The Construction of Melon Traceability System Based on QR Code for SHUNZI Vegetable Cooperative
}

\author{
Zhuang $\mathrm{Xu}^{1, \mathrm{a}}$, Hong-Mei Gao ${ }^{2, \mathrm{~b},{ }^{*}}$ \\ ${ }^{1,2}$ Economics and Management College, Tianjin Agricultural University, China \\ afrederickxuzhuang@163.com, bgaohongmei@126.com \\ ${ }^{*}$ Corresponding author
}

Keywords: Agricultural products traceability, QR code, Melon traceability system.

\begin{abstract}
Agricultural traceability system has diverse ways of implementations. Among them, with regard to identification QR code is a relatively unique identification new technology. Its application is wide and simple. Its research and application in Japan is also more mature. Based on a comprehensive study of domestic and foreign traceability technologies, this research project uses QR code technology to build a white guard traceability system for SHUNZI Vegetable Cooperatives in order to achieve the farm-to-table whole process recordability and traceability.
\end{abstract}

\section{Introduction}

With the continuous improvement of agricultural productivity production, Chinese people enjoy an increasingly high standard of living. They are beginning to have higher requirement for the quality and safety of agricultural products. As "the quality assurance system capable of recording and storing all relevant information during the entire products supply process [1]", traceability system is considered promising in ensuring the quality and safety of agricultural products; and the system may also help increasing the unit value of agricultural products. Based on a comprehensive study of domestic and foreign traceability technologies, this research project uses QR code technology to build a melon traceability system for SHUNZI Vegetable Cooperative in order to achieve the farm-to-table whole process recordability and traceability.

\section{Critical Theories}

The basic structure of QR code (Quick Response Code) as shown in Fig. 1, is a kind of matrix two-dimensional code.

Each QR code symbol is constitute of nominal square modules arranging in a square array. It consists of the coding region and functional image including viewfinder features, separators, positioning and correcting patterns. Functional image cannot be used for data encoding. The outside of symbol is surrounded by white space [2]. QR code was developed in September 1994 by the Japanese company DENSO. In addition to the general advantages of two-dimensional code, it also has the following characteristics [3]:

(1) It can achieve symbolization of large volume of information; its data can represent up to 7089 digits;

(2) It enables space-saving printing, using only a few millimeters of square corners to express all the necessary information;

(3) In addition to letters and numbers, it can also be expressed in Japanese kanas and Chinese characters;

(4) It also has 360-degree high-speed reading capability, which can be seen from its English name "quick response code". 
In July 2001, QR code was implemented as a Chinese national standard. Currently in the domestic market, QR code has been maturely applied in the traceability systems for invoices, train tickets, mobile payments, commercial goods, etc.

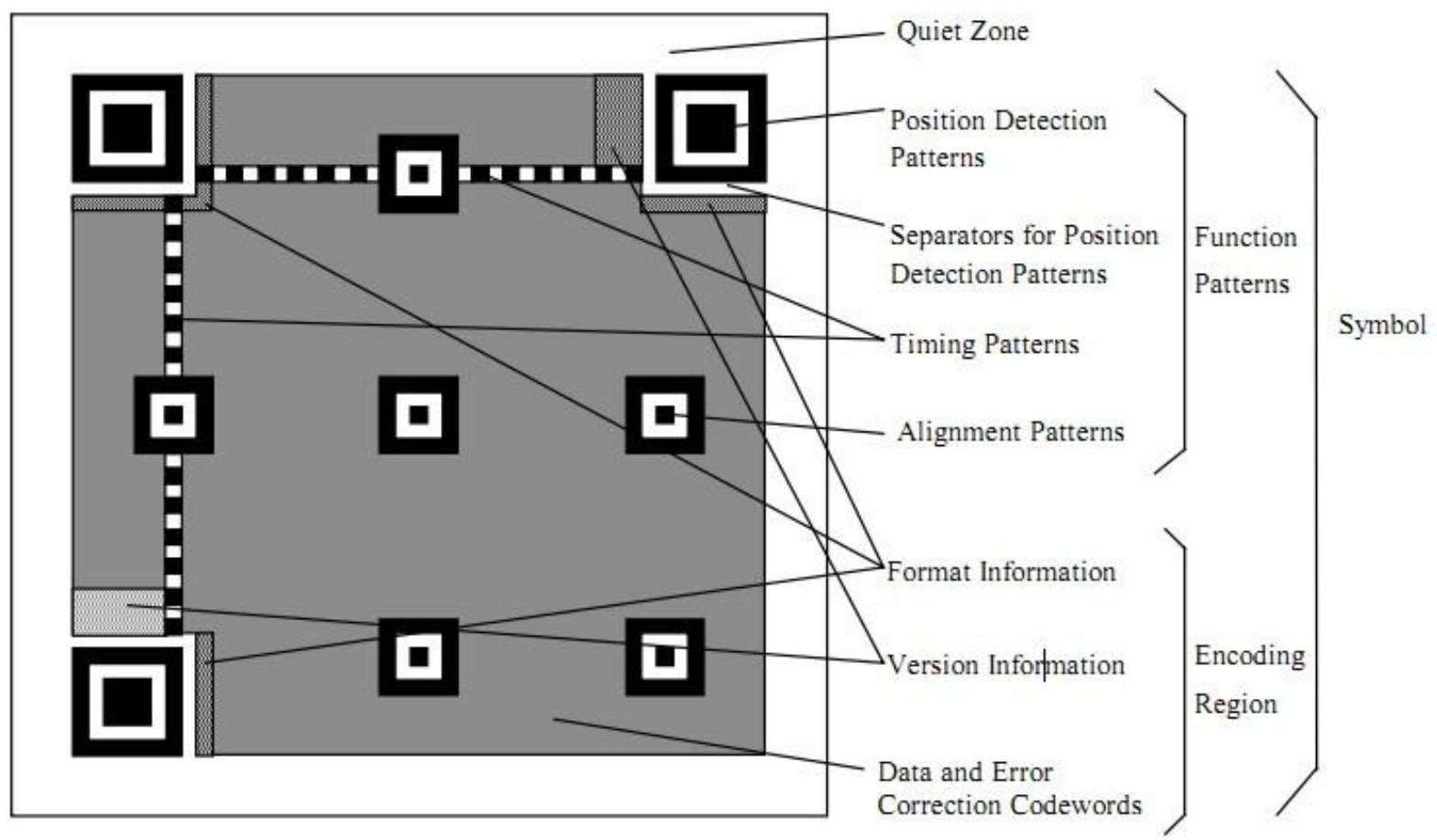

Source: Rapid response matrix national standard GB / T 18284-2000

Fig. 1 The Basic Structure of QR Code

\section{Overview of Melon Traceability System Construction}

\section{Overview of SHUNZI Vegetable Cooperative}

SHUNZI Vegetable Cooperative locates in Bijia Village, Xinkou Town, Tianjin Xiqing District. With more than 1,000 people and 600 acres of arable land, the village has begun to plant melon since 1992. It now has 400 acres of melons with an annual yield of 7 million kilograms. In September 2011, the village founded the SHUNZI Vegetable Cooperative, and applied the name "QINMEI" as melon trademark hence achieved specialization, intensification, organization, and large-scale cultivation of melon production. In November 2012, the Agricultural Ministry of China identified the village as one of the second batch of national "One Village One Product" model. However, due to the reason that melon is easy to cultivate and has a high vitality, it is widely grown in China. Today, as more and more villages began to replicate the melon cultivation model of Bijia village, some places by ways of organic pollution-free cultivation and further processing even created their characteristic melon industries. This makes SHUNZI Cooperative facing evermore serious threats including intensified competition, loss of self-characteristics, increasing homogenization, and weaker pricing power. Introduction of the Melon Traceability System will be one of the effective measures to resolve the current dilemma.

\section{Melon Cultivation, Storage and Logistics Processes}

Melon Cultivation. The main melon variety planted by SHUNZI Cooperative is "black brother" black skin melon, which is characterized by strong plant growth; a single fruit weights 15 to $20 \mathrm{~kg}$, and some can grow up to $50 \mathrm{~kg}$. Higher than average pulp density make the melon easy to be stored and transported [4]. The melon's production period lasts 150 to 180 days; sowing and seedlings planting is usually in March and April, and harvesting is in October. The process of planting melon in SHUNZI Cooperative is shown in Table 1. 
Tab. 1 SHUNZI vegetable cooperative's melon cultivation process

\begin{tabular}{|c|c|c|c|}
\hline Growth Stage & $\begin{array}{l}\text { Growth } \\
\text { Time }\end{array}$ & $\begin{array}{l}\text { Plantation } \\
\text { Task }\end{array}$ & Operating Rule \\
\hline \multirow{3}{*}{ Germination } & \multirow{3}{*}{ April } & Sowing & $\begin{array}{l}\text { Plant sterilized seeds into nutritive soil. Seedlings } \\
\text { sprout in about } 15 \text { days. }\end{array}$ \\
\hline & & $\begin{array}{l}\text { Seedling } \\
\text { planting }\end{array}$ & $\begin{array}{c}\text { Maintain temperature and moisture necessary to } \\
\text { seedling growth until it has } 4 \text { to } 5 \text { pieces of true } \\
\text { leaves. }\end{array}$ \\
\hline & & $\begin{array}{c}\text { Soil } \\
\text { preparation }\end{array}$ & $\begin{array}{l}\text { Plow the land, apply organic fertilizer and } \\
\text { superphosphate, and make ridges and gutters. }\end{array}$ \\
\hline \multirow{3}{*}{$\begin{array}{l}\text { Seedling } \\
\text { period }\end{array}$} & \multirow{3}{*}{$\begin{array}{l}\text { May to } \\
\text { June }\end{array}$} & Plantation & $\begin{array}{l}\text { Select robust seedlings, plant in field with a } 0.6 \mathrm{~m} \\
\text { hole spacing between them, and water the plant. }\end{array}$ \\
\hline & & Intertillage & $\begin{array}{l}\text { After watering, intertill multiple times to promote the } \\
\text { growth of roots. }\end{array}$ \\
\hline & & $\begin{array}{c}\text { top } \\
\text { application }\end{array}$ & $\begin{array}{l}\text { Apply decomposed manure fertilizer to ensure } \\
\text { adequate nutrition for seedlings. }\end{array}$ \\
\hline \multirow{6}{*}{$\begin{array}{l}\text { Vine Growth } \\
\text { Period }\end{array}$} & \multirow{6}{*}{$\begin{array}{l}\text { July to } \\
\text { August }\end{array}$} & Build frame & $\begin{array}{l}\text { After the seedlings begin to grow vines, build the } \\
1.5 \mathrm{~m} \text { high canopy frame (square frame). }\end{array}$ \\
\hline & & $\begin{array}{l}\text { Twist and } \\
\text { bury the } \\
\text { vines }\end{array}$ & $\begin{array}{l}\text { Twist the vines without female flowers at the base } \\
\text { around the frame and bury them into soil to help } \\
\text { them claim up frame. }\end{array}$ \\
\hline & & $\begin{array}{l}\text { Guide and } \\
\text { tie the vines }\end{array}$ & $\begin{array}{l}\text { Get rid of all the side vines, then guide vines along } \\
\text { the supporting pillars, tie them up every } 3 \text { to } 4 \text { knots. }\end{array}$ \\
\hline & & Pick Fruits & $\begin{array}{c}\text { When the fruit grow to } 0.5 \mathrm{~kg} \text {, remove the inferior } \\
\text { ones. }\end{array}$ \\
\hline & & $\begin{array}{c}\text { Fruits } \\
\text { Protection }\end{array}$ & $\begin{array}{l}\text { Protect the fruits against sunburn, and prevent them } \\
\text { from falling as a result of overweight. }\end{array}$ \\
\hline & & Harvest & $\begin{array}{c}\text { When the melon reach } 90 \% \text { maturity it's time to } \\
\text { harvest. It is important to prevent collision and } \\
\text { squeeze. }\end{array}$ \\
\hline
\end{tabular}

Melon Storage and Logistics. In September, the time of harvest, only a small part of melon will be sold; melons will be store in special warehouses and wait to be sold in time of Spring Festival, when the price and demand for melon are higher than usual times.

SHUNZI Cooperative uses the space saving rack storage method to store its melons. Each storage room is about 20 to 30 square meters, with a constant temperature of 10 to $15^{\circ} \mathrm{C}$, and relative humidity of about $70 \%$ to $75 \%$, the melon can store for 3 to 4 months or longer.

The market demand for SHUNZI vegetable cooperative's melons is quite good. A month before Spring Festival is the sales peak time, when many big vegetable retailors come to purchase melons. Melon transportation is usually by truck, so during transport turbulence, collision and squeeze should be avoided as much as possible. This is both to ensure the freshness of melon and to prevent the hindering of sales because of superficial damage.

\section{Construction Plan}

\section{Construction Goals}

(1) The basic goal is to make sure each melon produced by the cooperative has a unique "identity", and to ensure that all of the experience of the melon during the production and transportation process can be viewed after the scan of code.

(2) To make sure the system is easy to use.

(3) Make sure the system has the capability to urge and guarantee during melons' production, processing, and transportation stages, at any given time all the related personnel will record the accurate relevant information. 
(4) The ultimate goal is to protect the quality and safety of melon. If any accident happens that might have an impact on the quality and safety of melon, traceability system must respond immediately, track back to the source, and pin point the responsible parties.

\section{System Architecture}

The plan and design for SHUNZI Vegetable Cooperative Melon Traceability System are as follow: SHUNZI Vegetable Cooperatives Melon Traceability System consists of the following five parts: input system, data system, output system, query system and auxiliary system, as it is shown in Fig. 2.

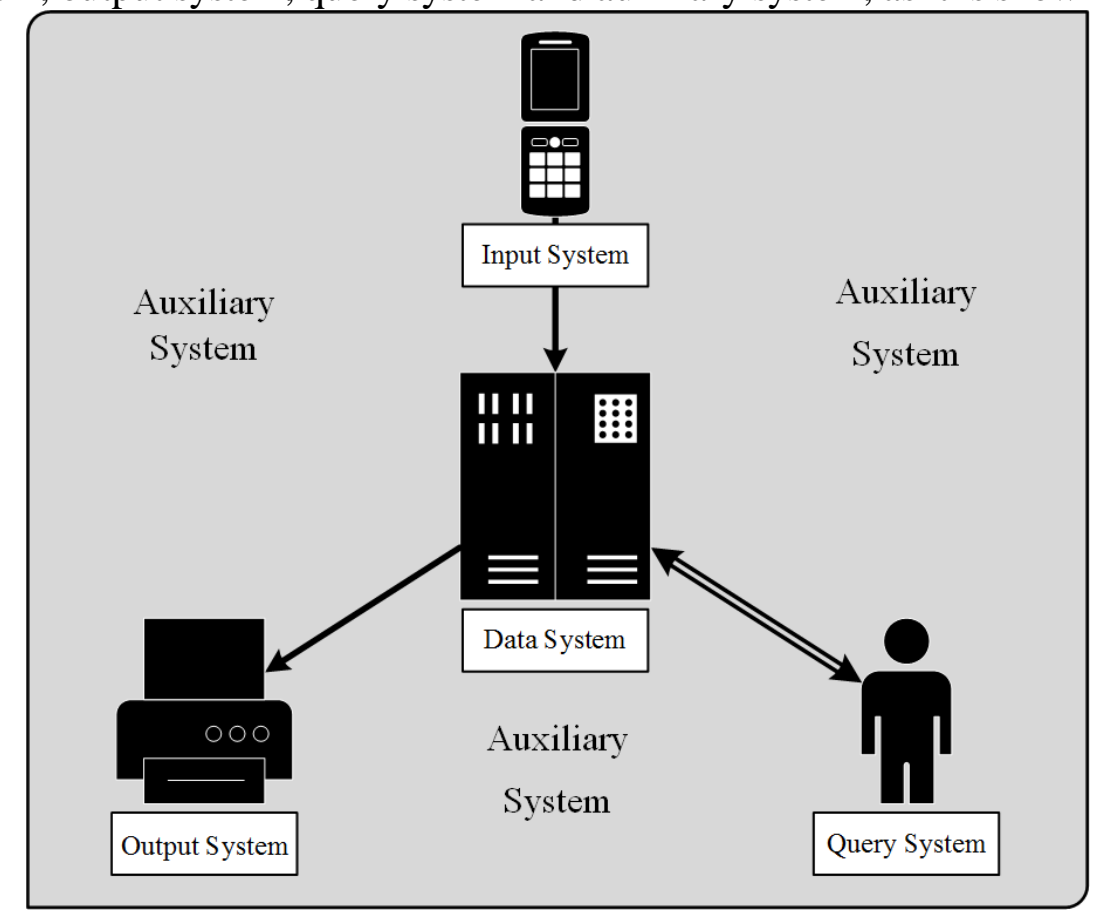

Fig. 2 The Structure of SHUNZI Vegetable Cooperative‘s Melon Traceability System

Data System. Data system is the core of melon traceability system. Its hardware is leased computer server, which is connected to other parts of the system through network, capable of information storage; its software constitutes of webpage service platform, and capable of information sorting, data output, information inquiry. Structure is shown in Fig. 3.

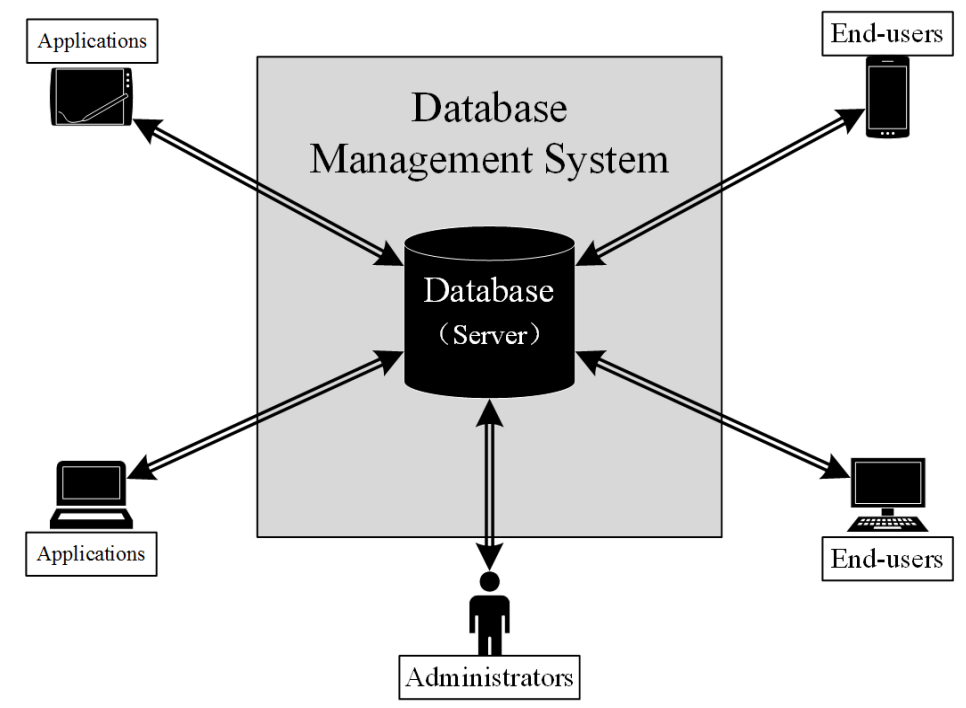

Fig. 3 Data System Sructure

According to database management system's relevant procedures, database receive information from the applications, administrators and end-users, then organize and store the information in accordance with 
database management system rules. When someone makes information inquiry request, the database response immediately and export the results. All of the activities need the network as media of communication.

Input System. The input system is operated by people relevant to melons' growth, storage, and transportation. Whenever someone performs a melon related job, job information will be promptly transferred to the database via the network (mainly wireless communications network).

The most prominent feature of SHUNZI Cooperative Melon Traceability System is its novel input method. Different from the traditional way of manual information input, this input system use scan code to input information. Users simply scan the QR code representative of different job, and enter the information to complete the action. Some QR codes symbolizing relative planting activitivies are shown in Fig. 4.

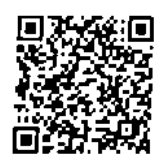

Watering

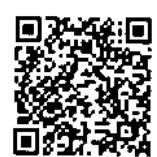

Weeding

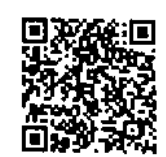

Fertilization

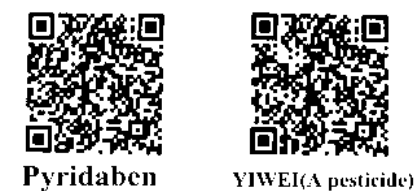

Fig. 4 Some QR Codes Symbolizing Relative Planting Activities

Output System. In the SHUNZI Cooperatives Melon Traceability System, the output system refers to the system that its output will get the corresponding QR code of a certain melon. Output system workflow is shown in Fig. 5.

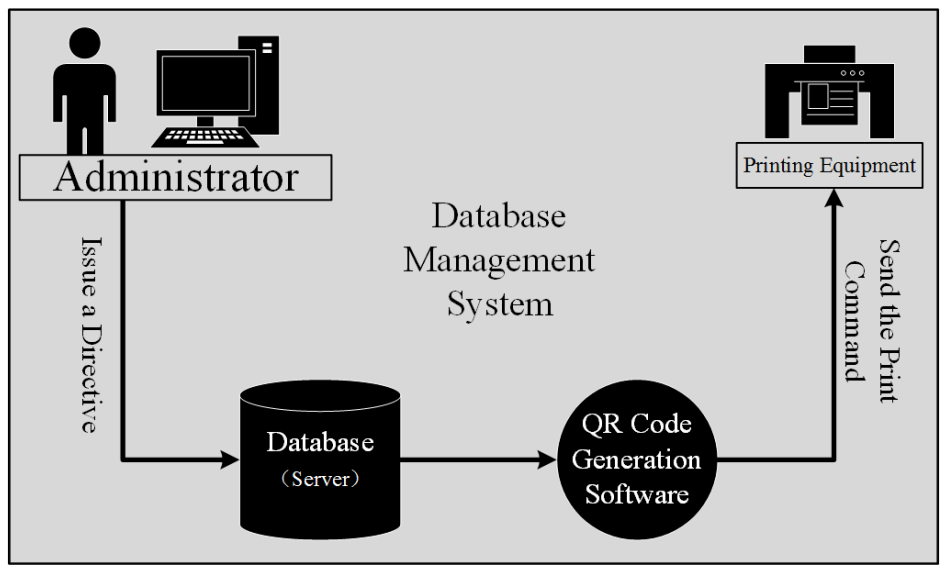

Fig. 5 Output System Workflow

When QR code is needed, the administrator issues a directive. The database retrieves relevant melon information, and transfers the code to $\mathrm{QR}$ code generation software to generate a $\mathrm{QR}$ code. Then the system sends the print command, and printing equipment prints label stickers.

Query System. The work method of query system is similar to a reverse input system. After purchase melons with traceable QR codes, consumers can immediately use portable devices with cameras and Internet connections, such as mobile phones, tablets, to scan the code. Information encoded in the QR codes will enable the canner to automatically open data system's information terminal, and retrieve the corresponding melon traceability data.

Auxiliary System. The auxiliary system for SHUNZI Vegetable Cooperatives Melon Traceability System is a complex software program system, which consists of multiple programs with different functions. It not only forms the basis for the operation of the whole system, but also monitors the operation of any given part of the system, and responses quickly to some irregular operations. Table 2 summarizes the role of the auxiliary system. 
Tab. 2 Role of the Auxiliary System

\begin{tabular}{|c|c|}
\hline Role & Task \\
\hline Firewall & To prevent unauthorized access, data leaks, and to examine suspicious access. \\
\hline $\begin{array}{c}\text { Data } \\
\text { Maintenance }\end{array}$ & $\begin{array}{c}\text { To warn administers, in case the database capacity is running low, database } \\
\text { hardware is damaged, or database is modified. }\end{array}$ \\
\hline $\begin{array}{c}\text { Hardware } \\
\text { Monitoring }\end{array}$ & $\begin{array}{c}\text { To warn administers when any hardware damage happens to the traceability } \\
\text { system. }\end{array}$ \\
\hline $\begin{array}{c}\text { Falsification } \\
\text { Prevention }\end{array}$ & $\begin{array}{c}\text { When the input information is irregular, incomplete, or of excessive quantity, } \\
\text { prohibits the input, and warn administers. }\end{array}$ \\
\hline $\begin{array}{c}\text { Administer } \\
\text { Management }\end{array}$ & $\begin{array}{c}\text { To control the login authority of server, and ensure authorized administers operate } \\
\text { within their authority. }\end{array}$ \\
\hline
\end{tabular}

\section{Project Implementation}

After modification, the SHUNZI Vegetable Cooperatives Traceability System entered the implementation phase. In April 2014, the project started with the planting of melon seedlings.

\section{Construction of Melon Traceability System}

In order of melon growth process, from April 2014 to January 2015, Melon Traceability System recorded from sowing to selling the entire process of melon production. Flow chart of the system's main operational model is shown Fig. 6.

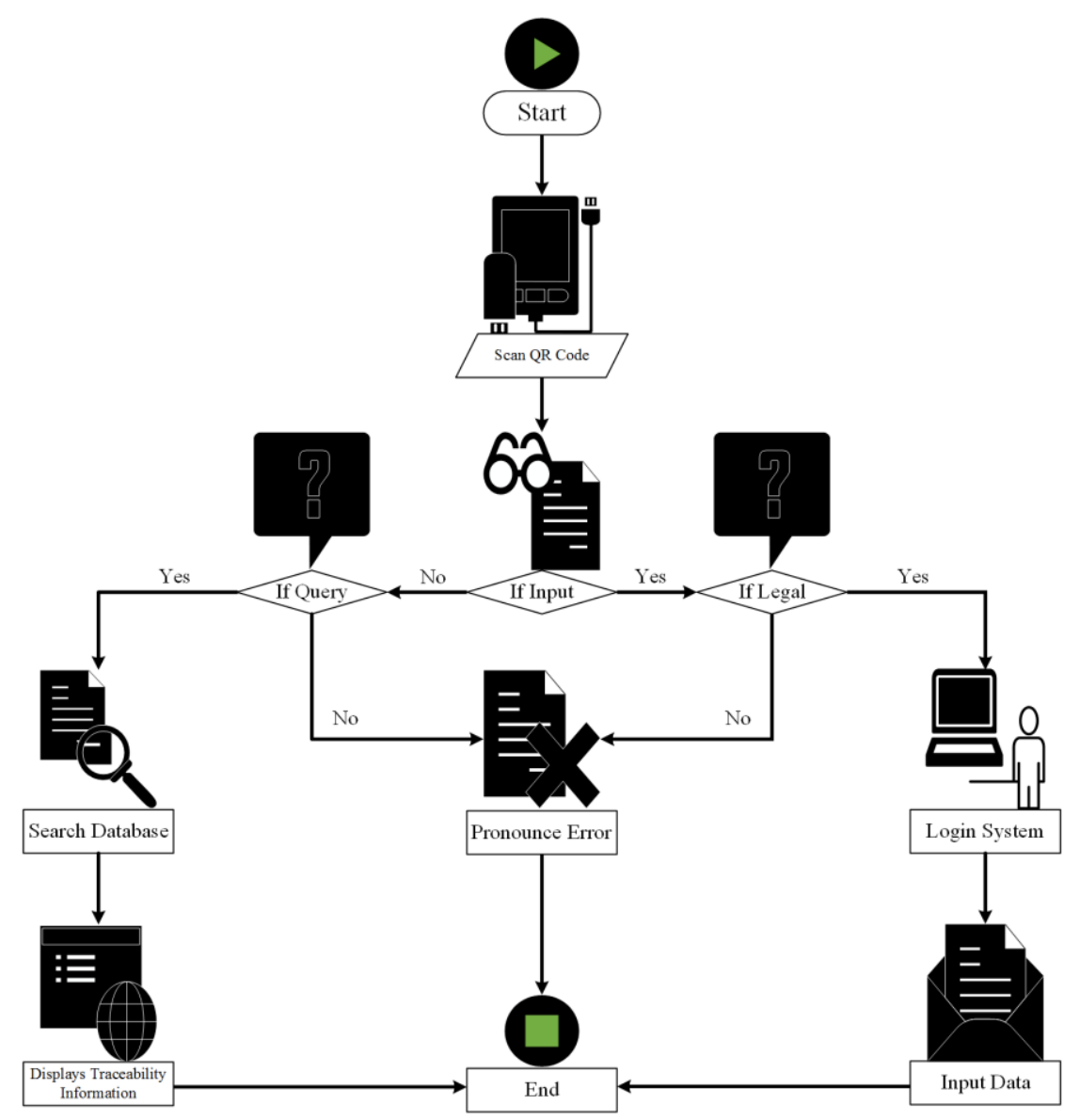

Fig. 6 Flow Chart of Melon Tracability System's Main Operational Model

Step 1: Use portable devices with Internet connection, such as mobile phones, tablet computers and code scanner to scan QR codes;

Step 2: Handheld terminals identify QR codes, web browsers get a response; 
Step 3: Browsers connect to the database management system, and the contents of QR codes trigger the appropriate procedures;

If the QR codes are representatives of cultivation or circulation activities, then:

Step 4: The system displays the login page. The input operator enters personal account information;

Step 6: Some activities may require further filling of detailed information. Information is input into the database. End of the entry process.

If the QR codes are representatives of melon traceability code, then:

Step 4: system identifies the melon identity information encoded, and searches the database;

Step 5: the system displays the traceability information in database on a web page, which signify the end of inquiry process.

According to program setting, if the $\mathrm{QR}$ code input code is neither input code nor traceability code, the system will immediately pronounce error and end the inquiry.

\section{System Modifications and Supplements}

In actual operation, responding to all kinds of feedbacks, the research team promptly made the following modification and supplements, to ensure the smooth operation of the traceability system.

First, in the case of pesticide applications, system procedures for relevant activities are completed, adding all possible pesticides suitable for melons, thus integrity of pesticide traceability system is ensured. Secondly, originally the system entries of pesticides and fertilizers are all chemical names, which the Cooperative members are unfamiliar with. In response to this situation, the research team changed all entries of pesticides and fertilizers to their trade names. Thirdly, due to the problem of web design, originally the data system web pages display only traditional Chinese characters. After modification, the simplified version of the web pages went online. Now the users can choose between the traditional or simplified version.

\section{Conclusion}

During the construction of the SHUNZI Vegetable Cooperatives Melon Traceability System, the research team consulted relevant domestic and foreign technologies, made use of knowledge from the field of agricultural cultivation, agriculture and forestry economic management, marketing, electronic information technology and logistics management, combined the circumstance of SHUNZI Cooperatives, using the QR code technology creatively, to build a well-targeted, highly pragmatic, and widely adaptable melon traceability system. And during implementation, we made further modification and improvement of this system, provided certain reference and experience for the construction of the traceability system for our country's agricultural products.

\section{Acknowledgement}

The successful completion of this project owning to the support of Tianjin College Students' Innovation and Entrepreneurship Training Program (Project Number 201410061021).

\section{References}

[1] Chen Honghua, Research on the Agricultural Products Traceability System of China, China Agriculture Press, Beijing, 2009.

[2] Zhang Chenghai, Zhang Duo, Logistics Barcode Practical Manual, Higher Education Press, Beijing, 2013.

[3] Yuuki Masuda, QR Code: Applicable Two-dimensional Code, J. China Logistics and Purchasing 20 (2003) 48-49.

[4] Zheng Huamei, Melon Vegetables, Beijing: China Agricultural University Press, Beijing, 2006. 